\title{
Experimental comparison of different techniques to measure saliva.
}

Citation for published version (APA):

Nederkoorn, C., de Wit, T., Smulders, F. T. Y., \& Jansen, A. T. M. (2001). Experimental comparison of different techniques to measure saliva. Appetite, 37, 251-252. https://doi.org/10.1006/appe.2001.0430

Document status and date:

Published: 01/01/2001

DOI:

10.1006/appe.2001.0430

Document Version:

Publisher's PDF, also known as Version of record

Document license:

Taverne

Please check the document version of this publication:

- A submitted manuscript is the version of the article upon submission and before peer-review. There can be important differences between the submitted version and the official published version of record.

People interested in the research are advised to contact the author for the final version of the publication, or visit the DOI to the publisher's website.

- The final author version and the galley proof are versions of the publication after peer review.

- The final published version features the final layout of the paper including the volume, issue and page numbers.

Link to publication

\footnotetext{
General rights rights.

- You may freely distribute the URL identifying the publication in the public portal. please follow below link for the End User Agreement:

www.umlib.nl/taverne-license

Take down policy

If you believe that this document breaches copyright please contact us at:

repository@maastrichtuniversity.nl

providing details and we will investigate your claim.
}

Copyright and moral rights for the publications made accessible in the public portal are retained by the authors and/or other copyright owners and it is a condition of accessing publications that users recognise and abide by the legal requirements associated with these

- Users may download and print one copy of any publication from the public portal for the purpose of private study or research.

- You may not further distribute the material or use it for any profit-making activity or commercial gain

If the publication is distributed under the terms of Article $25 \mathrm{fa}$ of the Dutch Copyright Act, indicated by the "Taverne" license above, 


\title{
Rapid communication
}

\section{Experimental comparison of different techniques to measure saliva}

\author{
Chantal Nederkoorn, Tessa de Wit, Fren T.Y. Smulders and Anita Jansen \\ Department of Experimental Psychology, Maastricht University
}

The secretion of saliva has digestive functions and is stimulated by (chemo)sensory input from food (Epstein et al., 1996). The amount of salivation can be an index of various psychological and physiological conditions. For example, hunger, palatability of food and eating disorders have been found to affect salivary secretion (LeGoff et al., 1988; Epstein et al., 1996). Also emotions like anger and fear can influence salivation. Therefore, measuring the amount of salivary secretion is an important tool in a wide research field.

Several techniques have been developed to measure salivation. An easily and frequently used method is the absorption of saliva by rolls of cotton. The weight of these rolls is determined before and after the measurement. This method has proved to be valid, reliable and sensitive (White, 1977). However, some adverse aspects of the procedure can make it less suitable. It is not appetizing to keep dental rolls in one's mouth, it is always necessary to interrupt the experimental procedure in order to insert and to remove the rolls and, finally, just the pressure of the rolls on the salivary glands can provoke a salivatory response, thus affecting the reliability of the experimental data.

Another technique is to measure the frequency of swallows. This can be determined by counting peaks in the electromyographic activity of the musculus digastricus. This technique allows effects on the timing of salivatory response to be monitored and it is not invasive or reactive, as is the cotton roll method. Experiments show that data collected with this technique correlate well with those obtained with cotton rolls, provided that certain precautions to prevent movement artifacts are taken (Pomerleau et al., 1983; Nederkoorn et al., 1999).

An interesting alternative method might be electrophysiological measurement of the activity of the parotid gland (Davis et al., 1990, 1996). An electrode is placed on the cheek, to lie over the parotid gland, and is referenced to the mastoid process. A peak in activity in response to lemon juice has been reported, with a latency of $2.5-3$ seconds, the highest peak

Address correspondence to: Chantal Nederkoorn, Maastricht University, Dept. of Experimental Psychology, P.O. Box 616, 6200 MD Maastricht, The Netherlands. around 3.5-7 seconds and recovery between 13 and 25 seconds (Davis et al., 1990). This response was reliably higher than that to water, and the initial report suggested a correlation between the recorded potential and salivary flow. However, further validation of this method is lacking. Since this noninvasive procedure may provide more than one index of the production of saliva, it seems worthwhile to test its validity and sensitivity.

The experiment briefly reported here was designed to test these three methods and to compare their results.

Forty-eight subjects participated, 24 women and 24 men. The participants were instructed not to eat anything nor to drink coffee for three hours before the experiment. None reported having a cold or any trouble smelling the stimuli. Salivation was measured with three dental rolls, one placed sublingually and two placed buccally. Physiological recordings were sampled at $500 \mathrm{~Hz}$. Swallowing was measured by two $\mathrm{Ag}-\mathrm{AgCl}$ electrodes, attached $1.0-1.5 \mathrm{~cm}$ from each other under the left jaw, below the anterior part of the musculus digastricus. A reference electrode was placed on the left mastoid process. Epochs with artifacts like coughing were removed. All signals were visually examined; after removal of any cues to experimental conditions, the first author counted the number of swallows. Parotid activity was measured by two Ag$\mathrm{AgCl}$ electrodes, attached to the right-hand cheek over the parotid gland, also placed $1.0-1.5 \mathrm{~cm}$ from each other, with a reference electrode on the right mastoid process. Raw electrophysiological activity was recorded between 0.01 and $10 \mathrm{~Hz}$.

Each measurement lasted two minutes and was made twice. Salivation was measured first with dental rolls and afterwards electrophysiologically (in counterbalanced sequences), because the two types of method interfere with each other (Nederkoorn et al., 1999). Between each measurement, the subject took a sip of mineral water and a 2-minute break. Baseline measurements were made at the beginning and end of the experiment.

The subject received four different stimuli in succession: a freshly cut lemon, chocolate, lasagna heated in a microwave, and chips of wood. Each stimulus was presented on a plate covered with a dish, which was removed at the start of a measurement. The order of the four stimuli was counterbalanced 


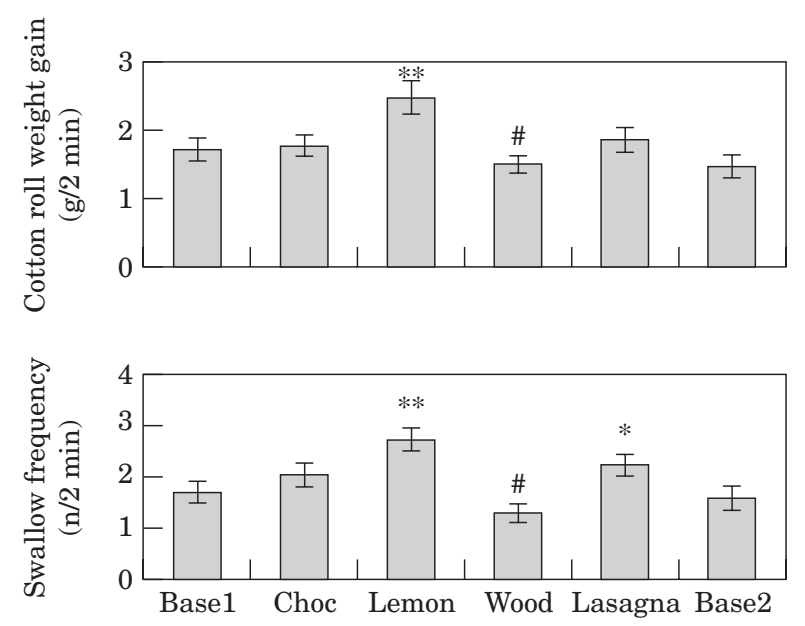

Figure I. Measurements of salivation (means with SEM bars) during the initial baseline, the four exposure periods and the final baseline. Upper histogram: increase in weight of cotton rolls. Lower histogram: swallow frequency. $*^{*} p<0.01, * p<0.05, \# p<0.06$.

across subjects using a Latin square. In total, 12 measurements of 2 min were made on each person.

The electrophysiological data of six women and one man were not recorded properly and are not included in the analyses. The differences between stimuli were tested by ANOVA for repeated measures; when the overall effect was significant, contrasts with the first baseline were specified.

In the recordings from the parotid gland, a peak in electrical activity was expected in response to the salivation-provoking stimuli. However, the signal oscillated around zero and did not seem to be influenced by the stimuli. Because no peak could be measured, the mean activity was calculated for the first 30 seconds (during which activity was expected to rise and fall). No significant influence of the stimuli was found, $F(5,36)=0.6$.

In the dental roll method, the salivatory response was significantly influenced by the different stimuli (Figure 1), $F(5,36)=5.9, p<0.001$. Relative to the initial baseline, subjects salivated more to lemon, $F(1,40)=13.3, p<0.001$, and marginally less to wood, $F(1,40)=3.8, p=0.057$.

The swallowing frequencies also showed significant variation among the salivatory responses to the stimuli (Figure 1), $F(5,36)=7.0, p<0.001$. Compared to the first baseline, subjects salivated more during exposure to lemon, $F(1,40)=$ $16.1, p<0.001$, and lasagna, $F(1,40)=4.8, p<0.05$, and marginally less to wood, $F(1,40)=4.0, p=0.051$.

Weight gain of cotton rolls and number of swallows were tested for correlations between the differences from initial baseline. The correlation was not significant during exposure to wood $(r=0.11)$, approached significance during exposure to lemon and the final baseline $(r=0.30, p=0.062 ; r=0.30$, $p=0.067)$ and was significant during exposure to chocolate $(r=0.33, p<0.05)$ and to lasagna $(r=0.39, p<0.05)$.

Thus the signal obtained by electrophysiological recording from the parotid gland did not match the descriptions of Davis et al. $(1990,1996)$ and was not influenced by the salivation-provoking stimuli, although the other two methods indicated that saliva was produced. To check if Davis et al. (1990) described a peak in a rectified and integrated signal of higher frequency, instead of the raw signal, recordings were made with band pass filters between 10 and $500 \mathrm{~Hz}$, rectifying and integrating the signal; no parotid activity was revealed. Therefore it can be concluded that electrophysiological measurement of activity of the parotid is not a reliable or valid method of measuring salivatory responses to stimulation by food.

Both the dental roll method and the swallowing method differentiated between the stimuli. The correlation between the two methods was not as high as in earlier research $(r=0.57$ in Nederkoorn et al., 1999), but reached significance or nearly so, with the exception of the wood stimulus to which there was low variance because of general lack of salivatory response. This experiment therefore reconfirms the validity of swallowing frequency as a measure of salivation.

Choice between the two methods will depend on the experimental needs. When electrophysiological apparatus is available and it is important for the measurement procedures not to influence appetite, counting swallows is recommended. When the measurements are made outside a laboratory setting or the subjects cannot sit quietly and relaxed, the dental roll weighing method is recommended.

Davis, C., Hing, M., \& Co M. (1990). A new measure of the human salivary response. Canadian Psychology 31 (2a), 302 (abstract).

Davis, C., Bauslaugh, T., Wintrup, A. (1996). Noninvasive recording of human salivary activity from surface electrodes: logic, method, and application. Psychophysiology 33, Supplement 1, s33.

Epstein, L. H., Paluch, R., \& Coleman (1996). Differences in saliva to repeated food cues in obese and nonobese women. Psychosomatic Medicine 58, 160-164.

LeGoff, D. B., Leichner, P., \& Spigelman, M. N. (1988). Salivary response to olfactory food stimuli in anorexics and bulimics. Appetite 11, 15-25.

Nederkoorn, C., Smulders, F. T. Y., \& Jansen, A. (1999). Recording of swallowing events using electromyography as a non-invasive measurement of salivation. Appetite 33, 361-369.

Pomerleau, O. F. Fertig, J., Baker, L., \& Cooney, N. (1983). Reactivity to alcohol cues in alcoholics and non-alcoholics: Implications for a stimulus control analysis of drinking. Addictive Behaviors 8, 1-10

White, K. D. (1977). Saliva: A review and experimental investigation of major techniques. Psychophysiology 14, 203-212. 